Dragan Ćoćkalo'

Dejan Đorđević ${ }^{2}$

Srđan Bogetić ${ }^{3}$

Dragana Sajfert ${ }^{4}$

Robert Minovski ${ }^{\text {b }}$
JEL: L26, D83, I25

DOI: $10.5937 /$ industrija41-3889

UDK:005.411:334.722(497.11);

005.511-053.81

Original Scientific Paper

\title{
Quality of Business, Entrepreneurship Education and Business start up Intentions Among Students in Serbia: Research Results $^{6}$
}

\author{
Article history \\ Received: 14. May 2013 \\ Sent for revision: 02 . July 2013 \\ Received in revised form: 21. October 2013 \\ Accepted: 21. October 2013 \\ Available online: 06. November 2013
}

\begin{abstract}
This paper will present findings of a research conducted among students in Serbia dealing with quality of business, entrepreneurship and business start-ups. Throughout a three year period the research has included 1990 examinees. The population is built on students from four universities and business schools directed towards business and management. The research has been conducted using a structured questionnaire. Among other, the research has shown that a number of examinees were not informed of the existence of financial incentives for starting a business. Interviewed students reported that they lack the knowledge of: the basics of entrepreneurship and small business, basic finance and accounting and foreign languages. In the opinion of students, Serbia is currently no suitable environment that encourages youth to start their own businesses. The results of this research point out the fact that the state must have the key role in this sphere of Serbian market through a creation of certain documents whose aim is
\end{abstract}

\footnotetext{
${ }^{1}$ University of Novi Sad, Technical faculty "Mihajlo Pupin" in Zrenjanin, Serbia, cole@tfzr.uns.ac.rs

${ }^{2}$ University of Novi Sad, Technical faculty "Mihajlo Pupin" in Zrenjanin, Serbia, djole@rocketmail.com

${ }^{3}$ Belgrade Business School, Serbia, sbogetic@yahoo.com

${ }^{4}$ University of Novi Sad, Technical faculty "Mihajlo Pupin" in Zrenjanin, Serbia, Z.sajfert@sbb.rs

${ }^{5}$ University of Ss. Cyril and Methodius in Skopje, Faculty of Mechanical Engineering, Macedonia, robert.minovski@mf.edu.mk

${ }^{6}$ ACKNOWLEDGEMENT: Publishing of this paper was supported by the Serbian Ministry of Education and Science: Grant TR 35017.
} 
Ćoćkalo D. et al.: Quality of Business, Entrepreneurship Education and Business...

promoting the concept of the young as entrepreneurs. A research of this scope has so far not been conducted on the territory of Serbia, and to the best of the authors' knowledge not even in the West Balkans region.

Keywords: Young entrepreneurs, Entrepreneurship education, Business Start-up, Competitiveness, Serbia.

\section{Kvalitet poslovnog i preduzetničkog obrazovanja u Srbiji: rezultati istraživanja}

Apstrakt: $U$ ovom radu se prezentuju rezultati istraživanja koje je sprovedeno među studentima $u$ Srbiji, a koje se bavi kvalitetom poslovanja, preduzetništvom $i$ pokretanjem sopstvenog biznisa. Tokom tri godine $u$ istraživanje je uključeno ukupno 1990 ispitanika. Populaciju su činili studenti četiri univerziteta i poslovnih škola, usmereni ka biznisu i menadžmentu. Istraživanje je sprovedeno pomoću strukturiranog upitnika. Između ostalog, istraživanje je pokazalo da izvestan broj ispitanika nije informisan o postojanju finansijskih podsticaja za pokretanje biznisa. Intervjuisani učenici prijavili su da im nedostaju znanja: osnove preduzetništva $i$ malog biznisa, osnovne finansija $i$ računovodstva $i$ stranih jezika. Po mišljenju studenata, Srbija trenutno nema odgovarajuće okruženje koje podstiče mlade da pokrenu sopstveni biznis. Rezultati ovog istraživanja ukazuju na činjenicu da država mora imati ključnu ulogu u ovoj sferi srpskog tržišta, kroz stvaranje određenih akata čiji je cilj promovisanje koncepta mladih kao preduzetnika. Istraživanje ove oblasti do sada nije sprovedeno na teritoriji Srbije, a prema saznanjima autora ni u regionu Zapadnog Balkana.

Ključne reči: Mladi preduzetnici, preduzetničko obrazovanje, pokretanje sopstvenog biznisa, konkurentnost, Srbija.

\section{Introduction}

Entrepreneurship is one of the leading promoters of economic development and creation of new working places through starting new companies, working places, opening of new markets. Entrepreneurship, in educative meaning, represents a source of new skills, knowledge, experiences and possibilities. To the market successfuly introduced enterpreneurial ideas and innovations are the basis of modern business, (Vukmirović, 2005). Entrepreneurship is especially emphasized in current conditions of global economic crisis which has caused great unemployment on the global level where entrepreneurship is observed as one of the ways for its reducing. First of all, it is related to young population - according to official statistics, we can notice the highest rate of youth unemployment compared to other age groups. 
Ćoćkalo D. et al.: Quality of Business, Entrepreneurship Education and Business...

The problem of youth unemployment is a complex field but it is limited by several factors which make an appropriate ambience for their encouraging. They are:

- Existence of appropriate programs for encouraging entrepreneurship of the young;

- Existence of institutions for support of the young for starting their own business;

- Existence of financial support to the young for business start up;

- Promotion of entrepreneurship of young people;

- Creation of legal framework for youth entrepreneurship.

Special attention is paid to achieving knowledge from the field of entrepreneurship of the young with the aim of their professional training. There is a great number of previous studies dealing with motivation (Scheinberg \& MacMillan, 1988), intentions (Crant, 1996) - elements which influence enterprising behaviour and starting-up business in different ways (Gartner, 1988; Scherer \& Brodzinski, 1990; Johannisson, Landström, \& Rosenberg, 1998), in other words, enterprising behaviour of the young, students (Johannisson et al., 1998) and self-employment (Kolvereid, 1996). Particularly interesting dimension of researching enterprising behaviour of the young makes the studies whose focus is on (for example, Aldrich, Renzulli, \& Langton, 1998): self-employed parents - self-employed children. This trend is expanding, concerning time (historical) and space (geographical) dimensions.

Recent (2003-) researches emphasize:

- Creative and cognitive potentials which students achieve within institutional system, in other words, focus on group of problems which students of different professional orientation have: Berglund and Wennberg (2006).

- Motivation and models of entrepreneurship motivation for the intention of becoming entrepreneurs: Segal, Borgia, \& Schoenfeld (2005).

- General attitudes, intentions and environment - themes of enterprising behavior, first of all, of young population, motivation, attitudes and intentions in interaction with the environment and education for entrepreneurship are obviously interesting topics to researchers all over the world; in this way, limited or cross-geographical/cross-cultural compared results give to these themes global character. The typical studies of this topic were: Franke and Lüthje (2004), Bhandari (2006), Harris and Gibson (2008), Schwarz, Wdowiak, Almer-Jarz, \& Breitenecker (2009), Boissin, Branchet, Emin, \& Herbert (2009) and Gasse and Tremblay (2011). 
Ćoćkalo D. et al.: Quality of Business, Entrepreneurship Education and Business...

\section{Entrepreneurship and the young - EU and Beyond}

Several international organizations such as OECD, ILO, World Bank and United Nations deal with issues related to encouragement and development of entrepreneurship among young people. Recently the increasing emphasis has also been placed, by governments across a range of countries (including EU), on stimulating greater commitment to enterprise and entrepreneurial activity, as part of broader economic goals. In addition to a pronounced growth of activity within schools to enhance students' awareness of enterprise opportunities, there has been an escalation of enterprise education and experience programmes. On the second OECD Conference of Ministers responsible for Small and medium-sized enterprises (SMEs), it was stated that: "Developing an entrepreneurial culture and fostering entrepreneurial attitudes and values has moved high on government agendas. Education and training (including lifelong training) in entrepreneurship and creativity are the preferred instruments for encouraging entrepreneurial behaviour in societies, and evidence suggests that such programmes can have an impact on entrepreneurial activity and enterprise performance" (OECD, 2009, p.10).

\subsection{Activities}

There is a wide range of activities which can be included in the category education for entrepreneurship. Education for entrepreneurship is concerned with the inculcation of a range of skills and attributes, including the ability to think creatively, to work in teams, to manage risk and handle uncertainty, (OECD, 2009, p.5). Considering entrepreneurial skills, the aims and tasks can be put into following categories that are not mutually excluded (OECD, 2009, p.5):

- The acquisition of key (or core) skills;

- The development of personal and social skills; and

- Skills relating to business start-up or financial literacy.

If the aim is encouragement of entrepreneurship, in the sense of encouraging someone's interest in entrepreneurship, three concrete aims of education can be distinguished (van der Zwan et al., 2013, p.4):

- Education may be targeted at developing entrepreneurship-related skills such as negotiation or communication skills;

- Education may be aimed at increasing knowledge, for example about entrepreneurs, about their role in society, or about economics or finance in general; and

- Development of entrepreneurial attitudes such as risk-taking behavior, creative and critical thinking, or self-confidence. 
Coćkalo D. et al.: Quality of Business, Entrepreneurship Education and Business...

The study of OECD Working Party on SMEs and Entrepreneurship (WPSMEE) had the aim "to strengthen the culture of evaluation within entrepreneurship education and to provide guidelines for evaluating in order to gain a better understanding of how to promote entrepreneurship education". (OECD, 2009, p.10) The objectives , among the others, were:

- to strengthen the case for supporting education for entrepreneurship activity,

- to deepen the understanding of the impact of education for entrepreneurship programmes,

- to encourage the development of commonality and comparability in the evaluation of education for entrepreneurship programmes.

With the aim to encourage entrepreneurship European Union represented „Entrepreneurship 2020 Action Plan“, (EUCommission, 2013a). A significant part of this plan is related to youth and promotion of entrepreneurship of young population. The plan is consisted of three poles:

- Entrepreneurial education and training to support growth and business creation;

- Strenghtening framework conditions for entrepreneurs by removing current structural obstacles and support in key phases of business cycle;

- Dynamization of entrepreneurial culture in Europe: fostering new generation of entrepreneurs.

Further, this Action Plan gives several suggestions for improving entrepreneurship through the following aims (EUCommission, 2013b):

- including entrepreneurship education and experience in school curricula,

- reducing the time it takes to start up a business, obtain the necessary licenses and permit and complete bankruptcy procedures,

- mentorship, advice and support schemes for women, seniors, migrants, the unemployed and other potential entrepreneurs.

As a result of these aims, in European Commission is considered that it is possible to create an ambience in which bureaucratic procedures will be shortened and greater support given to entrepreneurs. In the same time, it is expected that young people will achieve entrepreneurial knowledge and merely one entrepreneurial skill before finishing their education.

\subsection{Youth unemployment and attitudes about entrepreneurship}

The economic crisis is having an exceptionally severe impact on young people. According to data obtained from EU Commission (EUCommission, 2013c; EUCommission, 2013d), the EU youth unemployment rate stood at $23.6 \%$ in January 2013, more than twice as high as the adult rate. By the end Industrija, Vol.41, No.3, 2013 
Ćoćkalo D. et al.: Quality of Business, Entrepreneurship Education and Business...

of 2012, the rate of youth unemployment across the EU had risen from $22.6 \%$ in March to $23.4 \%$. In the second quarter of $2012,12.6 \%$ of youth were neither in employment nor in education or training, which is 2.3 percentage points higher than four years previously; 7.5 million Europeans aged 15-24 are neither in employment nor in education or training.

Table 1. Youth unemployment rates in most endangered counties, members of $E U^{*}$

\begin{tabular}{|l|c|c|c|c|}
\hline \multirow{2}{*}{} & \multicolumn{3}{|c|}{ Youth unemployment rate (in \%) } & $\begin{array}{c}\text { Number of young people } \\
\text { unemployed (in thousands) }\end{array}$ \\
\cline { 2 - 5 } & 2010 & 2011 & 2012 & Decembar 2012 \\
\hline Spain (ES) & 41.6 & 46.4 & 53.2 & 957 \\
\hline Slovakia (SK) & 33.9 & 33.5 & 34.0 & 85 \\
\hline Greece (EL) & 32.9 & 44.4 & 55.3 & 36 \\
\hline Latvia (LV) & 37.2 & 31.0 & 28.4 & 31 \\
\hline Lithuania (LT) & 35.3 & 32.2 & 26.4 & 610 \\
\hline Italy (IT) & 27.8 & 29.1 & 35.3 & 174 \\
\hline Portugal (PT) & 27.7 & 30.1 & 37.7 & 68 \\
\hline Ireland (IE) & 27.6 & 29.1 & 30.4 & \\
\hline \multirow{2}{*}{ * Seasonally adjusted, based on the Labour Force Survey and census data } \\
** Based on October data for EL and LV.
\end{tabular}

Source: Eurostat and EUCommission (2013c)

In the period from 15th June to 8th August 2012 the research was carried out "Entrepreneurship in the EU and beyond" (EUCommission, 2012) on the territory of EU 27 and in Croatia, Island, Israel, Norway, Switzerland, Turkey, Brazil, Russia, the United States, China, India, Japan and South Korea. This survey was carried out by TNS Opinion \& Social network. Over 42,000 respondents from different social and demographic groups were interviewed. The population of young people (age 15-24) who should be, according to their age, in regular system of education is especially interesting for the research. The methodology used is that of Eurobarometer surveys as carried out by the Directorate-General for Communication. Through this study and also through previous two similar studies the Directorate-General Enterprise and Industry wanted to represent development of entrepreneurship in the last decade.

When asked whether they would prefer to start their own business or take over an existing one, if they currently had the means to do either, in general, a majority of EU respondents say that they would rather set up a new business (54\%); the option choose to set up their own business is particularly popular in Romania (74\%), Poland (65\%) and Spain (64\%). In the population - age from $15-25$ this attitude is especially present (63\%). More than a quarter of in general EU respondents (28\%) say they would favour taking over an existing business. The most frequent fears which prevent them from starting business (age 15-24) are: the possibility of going bankrupt (55\%), risk of losing their property/home and irregular income (34\% each). 
Coćkalo D. et al.: Quality of Business, Entrepreneurship Education and Business...

In the Table 2 the attitudes of respondents age 15-24 about entrepreneurs and their role in society and business can be seen. A large majority (87\%) in the EU27 agree that entrepreneurs are job creators. Eight out of 10 EU respondents agree that entrepreneurs create new products and services that benefit all of us. But, a majority of EU respondents also agreed that: entrepreneurs take advantage of other people's work $(57 \%)$ and entrepreneurs only think about their own pockets $(52 \%)$.

Table 2. Attitudes of respondents age 15-24 about entrepreneurs (in percents)

\begin{tabular}{|c|c|c|c|c|c|c|c|c|}
\hline & \multicolumn{2}{|c|}{$\begin{array}{l}\text { Entrepreneurs } \\
\text { are job creators }\end{array}$} & \multicolumn{2}{|c|}{$\begin{array}{l}\text { Entrepreneurs } \\
\text { create new } \\
\text { products and } \\
\text { services that } \\
\text { benefit all of us }\end{array}$} & \multicolumn{2}{|c|}{$\begin{array}{c}\text { Entrepreneurs } \\
\text { take advantage } \\
\text { of other people's } \\
\text { work }\end{array}$} & \multicolumn{2}{|c|}{$\begin{array}{l}\text { Entrepreneurs } \\
\text { only think } \\
\text { about their } \\
\text { own pockets }\end{array}$} \\
\hline & Agree & Disagree & Agree & Disagree & Agree & Disagree & Agree & Disagree \\
\hline \multicolumn{9}{|l|}{ Age } \\
\hline $15-24$ & 87 & 11 & 81 & 18 & 51 & 46 & 49 & 49 \\
\hline \multicolumn{9}{|c|}{ Education (end of) } \\
\hline $15-$ & 81 & 16 & 74 & 21 & 62 & 32 & 60 & 35 \\
\hline 16-19 & 86 & 12 & 77 & 20 & 59 & 37 & 54 & 43 \\
\hline $20+$ & 90 & 9 & 82 & 16 & 54 & 43 & 47 & 50 \\
\hline Still studying & 89 & 10 & 81 & 18 & 49 & 48 & 46 & 51 \\
\hline
\end{tabular}

Source: EUCommission, 2012, p.107

Table 3 shows high percentage of respondents age 15-24 who didn't participate in activities or projects from the field of entrepreneurship during their education. These data seem disturbing because through courses/trainings during education is possible to influence significantly on developing skills of future entrepreneurs - they can be offered a chance to test their ideas by creating their own projects.

Table 3. Participation of respondents age 15-24 during education in training from entrepreneurial field (in percents)

\begin{tabular}{|l|c|c|}
\hline \multicolumn{1}{|l|}{} & Yes & No \\
\hline EU 27 & 23 & 76 \\
\hline Age & 34 & 66 \\
\hline $15-24$ & 9 & 90 \\
\hline Education (end of) & 19 & 81 \\
\hline $15-$ & 31 & 68 \\
\hline $16-19$ & 35 & 65 \\
\hline $20+$ &
\end{tabular}

Source: EUCommission, 2012, p.119 
Ćoćkalo D. et al.: Quality of Business, Entrepreneurship Education and Business...

Table 4. Help of school education in understanding entrepreneurship for different generations (in percents)

\begin{tabular}{|c|c|c|c|c|c|c|c|c|}
\hline & \multicolumn{2}{|c|}{$\begin{array}{l}\text { My school education } \\
\text { is helping/has helped } \\
\text { me to develop my } \\
\text { sense of initiative } \\
\text { and a sort of } \\
\text { entrepreneuria } \\
\text { attitude }\end{array}$} & \multicolumn{2}{|c|}{$\begin{array}{c}\text { My school education } \\
\text { is helping/has helped } \\
\text { me to better } \\
\text { understand the role } \\
\text { of entrepreneurs in } \\
\text { society }\end{array}$} & \multicolumn{2}{|c|}{$\begin{array}{c}\text { My school } \\
\text { education is } \\
\text { giving/has given me } \\
\text { skills and know- } \\
\text { how to enable me } \\
\text { to run a business }\end{array}$} & \multicolumn{2}{|c|}{$\begin{array}{l}\text { My school } \\
\text { education is } \\
\text { making/has made } \\
\text { me interested in } \\
\text { becoming an } \\
\text { entrepreneur }\end{array}$} \\
\hline & Agree & Disagree & Agree & Disagree & Agree & Disagree & Agree & Disagree \\
\hline \multicolumn{9}{|l|}{ Age } \\
\hline $15-24$ & 64 & 35 & 60 & 39 & 49 & 50 & 42 & 57 \\
\hline $25-39$ & 49 & 50 & 44 & 55 & 39 & 60 & 28 & 71 \\
\hline $40-54$ & 45 & 54 & 42 & 56 & 38 & 61 & 24 & 75 \\
\hline $55+$ & 49 & 47 & 46 & 49 & 40 & 56 & 26 & 70 \\
\hline \multicolumn{9}{|c|}{ Education (end of) } \\
\hline $15-$ & 37 & 59 & 37 & 58 & 31 & 66 & 23 & 74 \\
\hline $16-19$ & 46 & 52 & 44 & 53 & 38 & 60 & 26 & 72 \\
\hline $20+$ & 55 & 43 & 49 & 49 & 45 & 54 & 28 & 70 \\
\hline $\begin{array}{l}\text { Still } \\
\text { studying }\end{array}$ & 66 & 33 & 62 & 37 & 53 & 46 & 43 & 56 \\
\hline
\end{tabular}

Source: EUCommission, 2012, p.133

In what extent education in EU manages to educate different generations of entrepreneurs presents Table 4 where can be clearly noticed significant differences in the answers of respondents of different ages and different level of education. Half of EU respondents $(50 \%)$ agree that their school education helped them to develop a sense of initiative and a sort of entrepreneurial attitude. It is interesting that on national level agreement on this point is highest in Portugal (75\%), Romania (73\%) and Finland (64\%), and lowest in the UK (35\%) and Italy (40\%). Under half of EU respondents (47\%) agree that their school education helped them to better understand the role of entrepreneurs in society. Four out of $10 \mathrm{EU}$ respondents agree that their school education gave them the skills and know-how to enable them to run a business. $28 \%$ of respondents agree that their school education made them interested in becoming an entrepreneur.

A piece of information from this research according to which $34 \%$ of people who regard self-employment within five years as a feasible prospect have taken part in an entrepreneurship course seems interesting. Also $44 \%$ of respondents who are taking steps to start a business have taken part in an entrepreneurship course. Between $15 \%$ and $20 \%$ students who participate in SMEs program in secondary schools will start their own business in the future. 
Ćoćkalo D. et al.: Quality of Business, Entrepreneurship Education and Business...

\section{METHODOLOGY}

The results of research which dealt with the analysis of attitudes of young people related to their involvement in entrepreneurial process as well as with their comprehension about success of business practice in Serbian companies, represented opinions of future experts and executives. The research in this form was being carried out for three years in a row (20102012) on the territory of Republic of Serbia in 16 towns and municipalities Beograd, Bačka Palanka, Novi Sad, Subotica, Požarevac, Kragujevac, Šabac, Kraljevo, Čačak, Ivanjica, Sremska Mitrovica, Paraćin, Zrenjanin, Alibunar, Niš and Jagodina, during November and December. The survey is carried out by questionnaire. The population is built of students from four universities and business schools. It includes totally 1990 students directed towards business and management. The average age of examinees is about 22 years. Around $38 \%$ men and $62 \%$ women participate in the sample. The research from 2012 was the most extensive and it involved 755 students.

Hypotheses of the research were:

HO Students in Serbia want to go into private business but: they do not have appropriate knowledge and skills, they are suspicious that conditions and quality level are not good enough in private companies, they are not confident considering the ambience of work.

H1 Students accept the possibility of doing private business but they are aware of economic situation in which they live.

H2 Some skills and knowledge should be encouraged so the students could start and manage their own business successfully.

H3 The state is a key factor in providing ambience and support for business start up.

During the checking phase of statistically relevant differences in the answers provided by students Chi-square $\left(\mathrm{X}^{2}\right)$ test was used, or Cramér's V, coefficient of association at determination of two variables' strength. Strength of association between two variables (or Cramér's $V$ ) varies from 0 (no association between the variables) to 1 (complete association) and can reach 1 only when the two variables are equal to each other. The level of significance was adopted in relation to frequency of answering $p<.05$. If the Chi-square test was not significant, and $p$-level greater than .05, significant differences are random and frequency response to a specific question are treated as equals.

\section{Quality of Serbian Business and youth's Entrepreneurship Behaviour}


Ćoćkalo D. et al.: Quality of Business, Entrepreneurship Education and Business...

\subsection{Unemployment in Serbia}

Unemployment represents one of the greatest problems in Serbia. Official statistics shows permanent increase of unemployment. According to the Statistical Office of the Republic of Serbia (RZSRS, 2013) in 2012 there were 701.138 unemployed people (310.123 women), and the total unemployment rate was the highest since 2000 and stood at 23.9\% (Figure 1). Figure 2 presents the total unemployment rate for all the countries of the former Yugoslavia for the period 2009-2012. Compared to other countries, Macedonia has the highest total unemployment rate, Slovenia the lowest, while Serbia has the highest growth of total unemployment rate for this period $(+7.8 \%)$.

Figure 1. Unemployed population aged 15 and over with total unemployment rate for the period 2000-2012, Serbia (RZSRS, 2013)

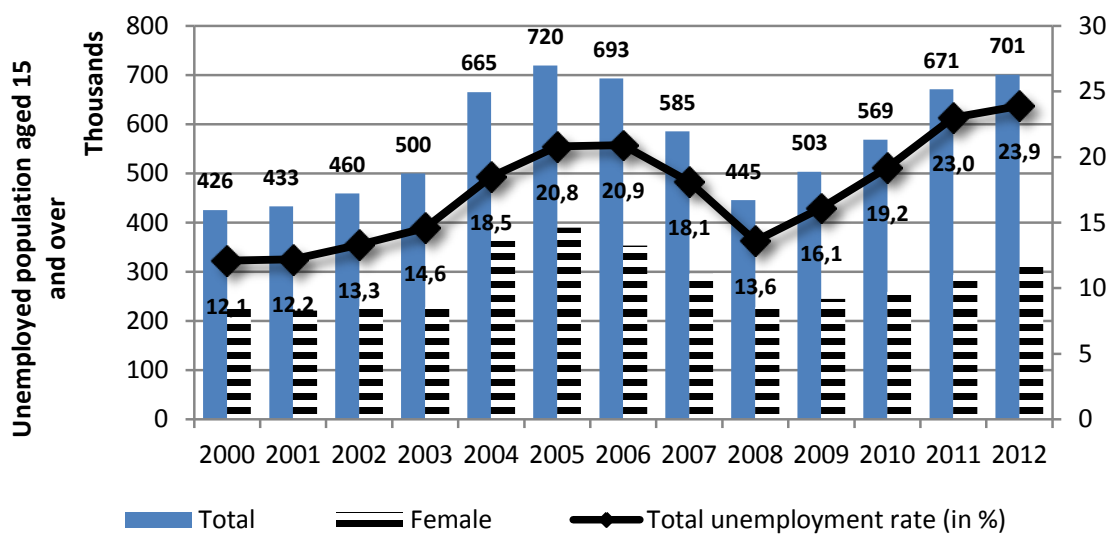

Figure 2. Total unemployment rate (in \%) for all the countries of the former Yugoslavia in period 2009-2012. (based on Labour Force Survey) 
Ćoćkalo D. et al.: Quality of Business, Entrepreneurship Education and Business...

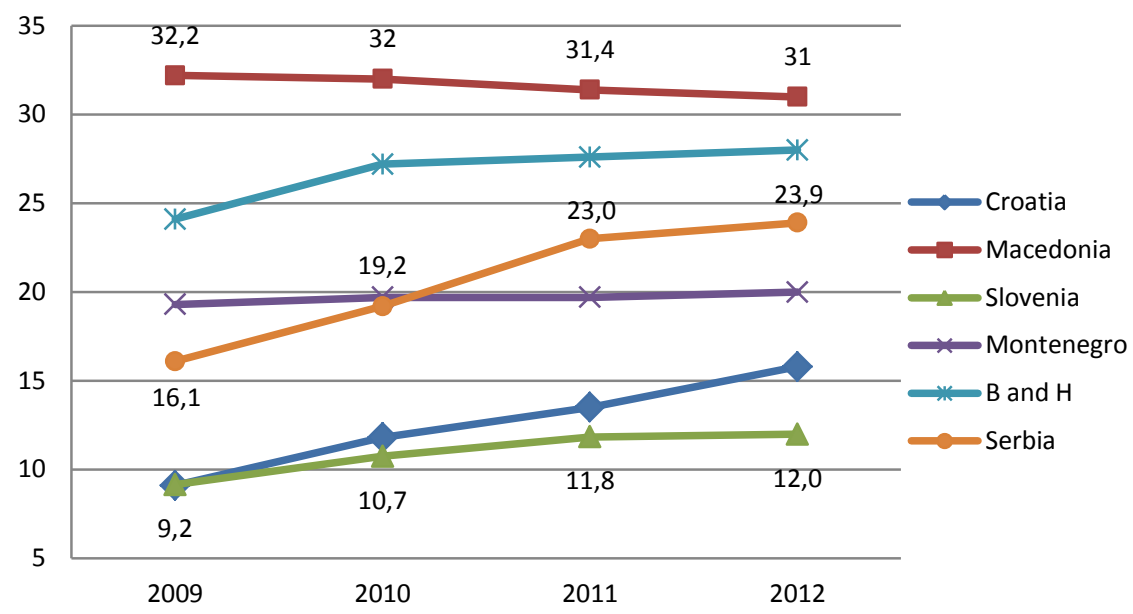

Unemployment rate in Serbia in April 2013 increased by 1.7\% if compared to October 2012, while employment rate increased by $0.4 \%$. Unemployment rate in April 2013 decreased by $1.4 \%$, compared to April 2012, while employment rate increased by $2 \%$. Informal employment rate in April 2013 increased by $1.2 \%$, in comparison to April 2012, and by $0.3 \%$, related to October 2012 . The indicators are given in Table 5.

Table 5. Unemployment and employment rates October 2011 and April and October 2012, and April 2013 - parallel review

\begin{tabular}{|c|c|c|c|c|}
\hline & October 2011 & April 2012 & October 2012 & April 2013 \\
\hline Unemployment rate & 23.7 & 25.5 & 22.4 & 24.1 \\
\hline Employment rate & 35.3 & 34.3 & 36.7 & 36.3 \\
\hline Informal employment rate & 17.8 & 17.0 & 17.9 & 18.2 \\
\hline
\end{tabular}

According to data for June 2013 (RSNSZ, 2013; RZSRS, 2013), there were 776,354 unemployed people, which is for 14,868 more than in Decemebr $2012(761,486)$ - Table 6 . Majority of unemployed people are in the age group 25-39 (298,057), where is also the biggest total unemployment difference for these two monts $(+8,127)$. Young people aged 15-24 make nearly $14 \%$ and women more then one half of the total unemployed people number.

Data of the studies which mostly NGO dealth with aided by international organizations (for example, USAID), as well as data from EU countries which were said before, among the others, pont at significant role which Serbia may have in youth employment by encouraging entrepreneurial initiative and directing education towards entrepreneurship. Starting their own business can Industrija, Vol.41, No.3, 2013 
Ćoćkalo D. et al.: Quality of Business, Entrepreneurship Education and Business...

be one of the ways for reducing unemployment in youth population. Experiences of some developed countries as well as EU show that it is the only way for developing national economy.

Table 6. Unemployed persons at December 2012 and June 2013 with monthly differences in total unemployment in the same period (RSNSZ, 2013)

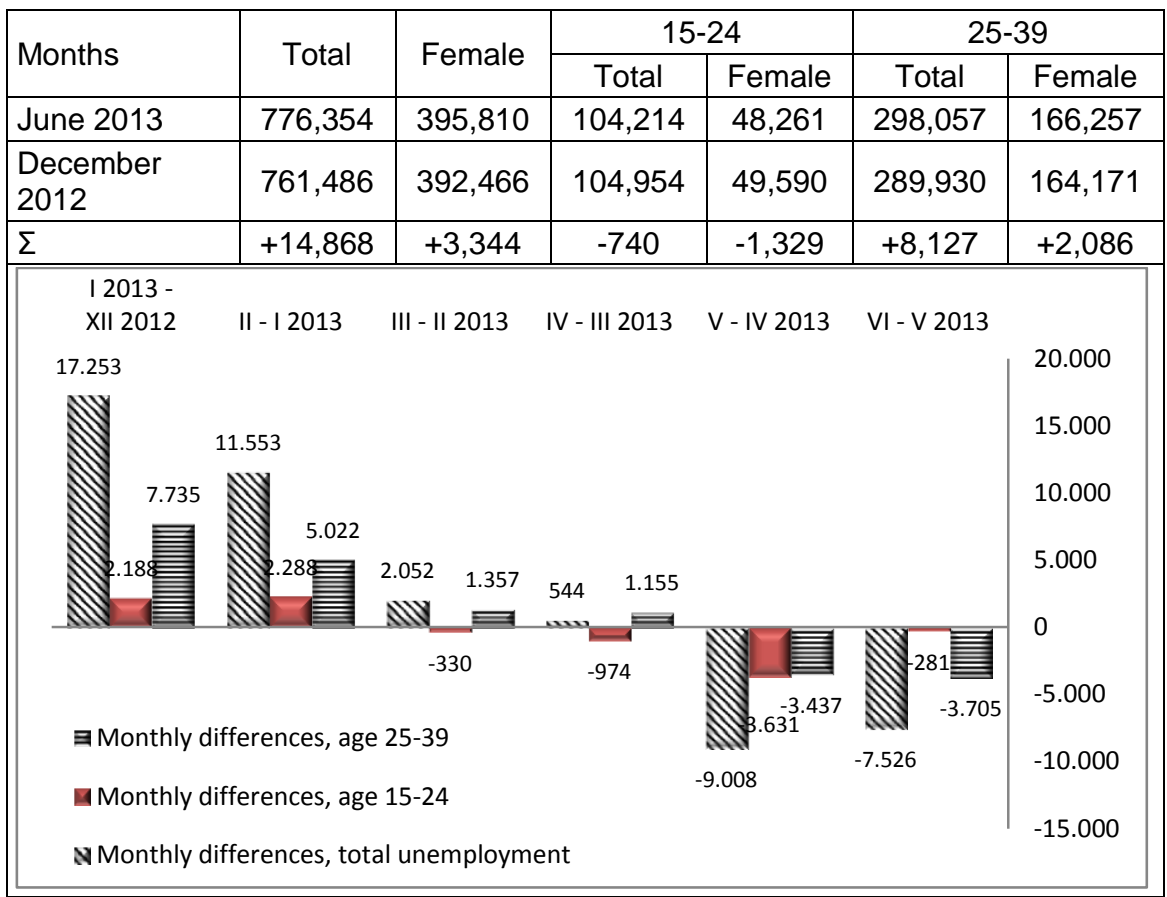

Source: Statistical Office of the Republic of Serbia and National Employment Service of the Republic of Serbia

\subsection{The analysis of research results}

The focus of the research "Analysis of attitudes and opinions of youth related to business start up by implementation of corporative responsible business and improvement of company's competitiveness" was about starting and managing own business. In the period of five years (2008-2012) data were collected from students of faculties and high schools oriented in their work towards business which were related to their opinions about business start up, corporative responsible business and competitiveness of Serbian economy. Due to changes in methodology, only data provided by researching from 2010 to 2012 will be presented and data and analysis from the previous two years that could be compared (Đorđević, Bogetić, \& Ćoćkalo, 2010a; Đorđević, 
Ćoćkalo D. et al.: Quality of Business, Entrepreneurship Education and Business...

Ćoćkalo, \& Bogetić, 2010b). They should illustrate and confirm previously stated assertions.

Total data show that there are differences in frequency of answers given to the question "Would you start up your own business?" $\left(X^{2}(1, N=1985)=\right.$ $512.88, p=.000)$. Respondents chose the answer "yes" more frequently $(75.3 \%)$. Hi-square test, however, shows that there is statistically significant connection between the year in which the research was carried out and this question - declining trend for their readiness for business start up is obvious (Table 7). According to sex, male respondents were more willing $(78.0 \%)$ to start up their business than female respondents (73.9\%). Considering their parents' vocation, respondents whose parents have private business were the ones who gave the answer "yes" to this question $-81.5 \%$ in the situations where father is in private business $\left(\mathrm{X}^{2}(5, N=1854)=9.426, p=.093>.05, \mathrm{~V}\right.$ $=.071, p=.093)$ and $80.7 \%$ when mother is in private business $\left(\mathrm{X}^{2}(5, N=\right.$ 1907) $=14.327, p=.014^{*}, \mathrm{~V}=.087, p=.014$ ).

As reasons for not starting up business the students - respondents give three statements most frequently (table 8): "insufficient financial means", "insecure political and economic situation" and "I don't have the right idea". Potentiation of attitude "I don't have the right idea" points at compatibility with conclusions of the 2008-2009 research, according to which is necessary to insist on developing entrepreneurial skills within the concept of promoting the concept of entrepreneurship on faculties and high schools, (Đorđević et al., 2010a; Đorđević et al., 2010b).

Table 7. Trends for business start up readiness

\begin{tabular}{|c|c|c|c|c|c|c|c|c|c|c|}
\hline & \multicolumn{9}{|c|}{ Year } \\
\hline & & \multicolumn{3}{|c|}{2010} & \multicolumn{3}{|c|}{2011} & \multicolumn{3}{|c|}{2012} \\
\hline & & Frequ. & $\begin{array}{l}\text { Column } \\
\text { frequ. } \\
\text { (in \%) }\end{array}$ & $\begin{array}{l}\text { Row } \\
\text { frequ. } \\
\text { (in \%) } \\
\end{array}$ & Frequ. & $\begin{array}{l}\text { Column } \\
\text { frequ. } \\
\text { (in \%) }\end{array}$ & \begin{tabular}{c|} 
Row \\
frequ. \\
(in \%) \\
\end{tabular} & Frequ. & $\begin{array}{l}\text { Column } \\
\text { frequ. } \\
\text { (in \%) }\end{array}$ & $\begin{array}{l}\text { Row } \\
\text { frequ. } \\
\text { (in \%) } \\
\end{array}$ \\
\hline \multirow{2}{*}{$\begin{array}{l}\text { Would } \\
\text { you start } \\
\text { up own } \\
\text { business? }\end{array}$} & Yes & 466 & $80.6 \%$ & $31.1 \%$ & 502 & $76.9 \%$ & $33.5 \%$ & 529 & $70.2 \%$ & $35.3 \%$ \\
\hline & No & 112 & $19.4 \%$ & $23.0 \%$ & 151 & $23.1 \%$ & $30.9 \%$ & 225 & $29.8 \%$ & $46.1 \%$ \\
\hline \multicolumn{11}{|c|}{ Chi-square test: $X^{2}=20.441 ; d f=2 ; p=.000^{*} ; V=.101^{*} ; p=.000$} \\
\hline
\end{tabular}

Source: Author

Researching further, the level of quality of work in private companies as potential cause of insecurity for doing private business, the following statement was given "Conditions of work in private company are more favourable than conditions in companies with other form of ownership." The students insisted on the answer "Disagree" $(25.7 \%)\left(X^{2}(4, N=1987)=\right.$ Industrija, Vol.41, No.3, 2013 
Ćoćkalo D. et al.: Quality of Business, Entrepreneurship Education and Business...

101.644, $p=.000$ ). It is noticeable that since 2010, when students most frequently $(33.9 \%)$ disagreed with this statement, they have changed their attitude so in $2011(28.6 \%)$ and in $2012(24.4 \%)$ they insisted on the answer "Mostly agree" $-V=.117$. Although, answering the question "Do you think that in our country people are not informed about real business possibilities of private companies?" they were categorical. Though there are differences in frequency of giving the answer to this question $\left(X^{2}(4, N=1985)=1297.365\right.$, $p=.000)$, a connection between the year in which the research was carried out and this question is obvious $(V=.116)$,the most frequent answers were "Agree" (45.9\%) and "Mostly agree" (31.7\%).

Table 8. Reasons for not starting up business

\begin{tabular}{|l|c|c|c|c|c|c|c|c|c|}
\hline & \multicolumn{7}{|c|}{2010} & \multicolumn{3}{c|}{2011} & \multicolumn{3}{c|}{2012} \\
\cline { 2 - 10 } & Frequ. & $\begin{array}{c}\text { Column } \\
\text { frequ. } \\
\text { (in \%) }\end{array}$ & $\begin{array}{c}\text { Row } \\
\text { frequ. } \\
\text { (in \%) }\end{array}$ & Frequ. & $\begin{array}{c}\text { Column } \\
\text { frequ. } \\
\text { (in \%) }\end{array}$ & $\begin{array}{c}\text { Row } \\
\text { frequ. } \\
\text { (in \%) }\end{array}$ & Frequ. & $\begin{array}{c}\text { Column } \\
\text { frequ. } \\
\text { (in \%) }\end{array}$ & $\begin{array}{c}\text { Row } \\
\text { frequ. } \\
\text { (in \%) }\end{array}$ \\
\hline $\begin{array}{l}\text { I don't have } \\
\text { the right idea }\end{array}$ & 41 & $25.8 \%$ & $26.5 \%$ & 46 & $24.1 \%$ & $29.7 \%$ & 68 & $26.1 \%$ & $43.9 \%$ \\
\hline $\begin{array}{l}\text { I don't have } \\
\text { enough knowledge }\end{array}$ & 15 & $9.4 \%$ & $13.4 \%$ & 34 & $17.8 \%$ & $30.4 \%$ & 63 & $24.1 \%$ & $56.3 \%$ \\
\hline $\begin{array}{l}\text { Insufficient } \\
\text { financial means }\end{array}$ & 78 & $49.1 \%$ & $26.4 \%$ & 106 & $55.5 \%$ & $35.9 \%$ & 111 & $42.5 \%$ & $37.6 \%$ \\
\hline $\begin{array}{l}\text { Little experience in } \\
\text { managing companies }\end{array}$ & 27 & $17.0 \%$ & $22.7 \%$ & 55 & $28.8 \%$ & $46.2 \%$ & 37 & $14.2 \%$ & $31.1 \%$ \\
\hline $\begin{array}{l}\text { Insecure in self } \\
\text { abilities }\end{array}$ & 1 & $.6 \%$ & $4.2 \%$ & 14 & $7.3 \%$ & $58.3 \%$ & 9 & $3.4 \%$ & $37.5 \%$ \\
\hline $\begin{array}{l}\text { Insecure political and } \\
\text { economic situation }\end{array}$ & 54 & $34.0 \%$ & $22.4 \%$ & 95 & $49.7 \%$ & $39.4 \%$ & 92 & $35.2 \%$ & $38.2 \%$ \\
\hline $\begin{array}{l}\text { Lack of good partners } \\
\text { for business start up }\end{array}$ & 25 & $15.7 \%$ & $24.8 \%$ & 24 & $12.6 \%$ & $23.8 \%$ & 52 & $19.9 \%$ & $51.5 \%$ \\
\hline I'm not interested & 19 & $11.9 \%$ & $26.0 \%$ & 16 & $8.4 \%$ & $21.9 \%$ & 38 & $14.6 \%$ & $52.1 \%$ \\
\hline Other & 5 & $3.1 \%$ & $45.5 \%$ & 6 & $3.1 \%$ & $54.5 \%$ & 0 & $.0 \%$ & $.0 \%$ \\
\hline Chi-square test: $X^{2}=77.720 ; \mathrm{df}=18 ; \mathrm{p}=.000$ \\
\hline
\end{tabular}

Source: Author

For improving quality of business and for starting and managing own company certain knowledge are necessary that should be provided to youth whether through formal or informal forms of education. According to the results of this research, students-respondents state most frequently three fields in which they lack appropriate knowledge for starting and managing their own business (figure 3): elements of entrepreneurship and small business, elements of finance and accounting and foreign languages. 
Ćoćkalo D. et al.: Quality of Business, Entrepreneurship Education and Business...

Figure 3. Fields of knowledge that young people do not have to run their own business

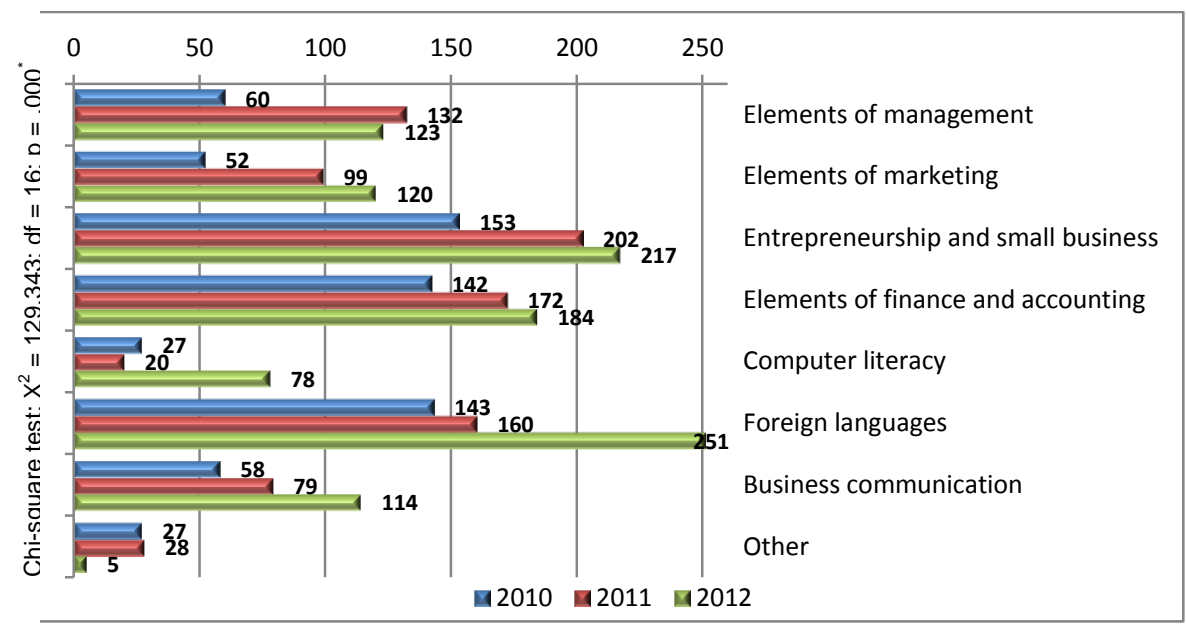

Source: Author

Ambience which the state should provide in order to stimulate young entrepreneurs to start up their business and manage it qualitatively represents a union of several elements among the most influential are: political and economic situation, legislation, organized market, tax policy, promotion of entrepreneurship and education for entrepreneurship. The results of the research show that for the time being there is no ambience appropriate for stimulating business start up $\left(X^{2}(1, N=1989)=928.548, p=.000\right)-$ in $84.2 \%$ cases the respondents said so. The most frequent obstacles for this are (table 9): lack of financial means, unstable political and economical situation and too high taxes. There is a five-year-trend within which in 2008 and $200978.7 \%$ of respondents expressed unsatisfaction with the ambience for starting and developing their own business and they numbered the following factors as obstacles: unstable political and economical situation (36.5\%), long and complicated registration procedure (13.7\%), and high taxes $(10.1 \%)$, (Đorđević et al., 2010a; Đorđević et al., 2010b).

Interviewed students mostly think (62.6\%) that entrepreneur must rely on own financial means in business start up $\left(\mathrm{X}^{2}(3, N=1967)=1542.578, p=.000\right)$. The reason may be the consequence of inadequate confidence in banks and other institutions which offer financial means for start ups. The attitude of students supports this, namely $(56.9 \%)$ of the interviewed said that start-up loans of commercial banks are not favourable $\left(\mathrm{X}^{2}(1, N=1981)=39.859, p=\right.$ .000 ), because they are loaded by high interest rates and long process for getting the means (Table 10). Data which can be compared and are provided Industrija, Vol.41, No.3, 2013 
Ćoćkalo D. et al.: Quality of Business, Entrepreneurship Education and Business...

by the research from 2008 and 2009 (Đorđević et al., 2010a; Đorđević et al., $2010 b$ ), point at the obvious five-year-trend; respondents were not satisfied by conditions for start up loans even then (54\%), and the most significant reason for them were high taxes (33.8\%).

Table 9. The biggest obstacles for business start up

\begin{tabular}{|l|c|c|c|c|c|c|c|c|c|}
\hline \multirow{2}{*}{} & \multicolumn{7}{|c|}{2010} & \multicolumn{3}{c|}{2011} & \multicolumn{3}{c|}{2012} \\
\cline { 2 - 11 } & Frequ. & $\begin{array}{c}\text { Column } \\
\text { frequ. } \\
\text { (in \%) }\end{array}$ & $\begin{array}{c}\text { Row } \\
\text { frequ. } \\
\text { (in \%) }\end{array}$ & Frequ. & $\begin{array}{c}\text { Column } \\
\text { frequ. } \\
\text { (in \%) }\end{array}$ & $\begin{array}{c}\text { Row } \\
\text { frequ. } \\
\text { (in \%) }\end{array}$ & Frequ. & $\begin{array}{c}\text { Column } \\
\text { frequ. } \\
\text { (in \%) }\end{array}$ & $\begin{array}{c}\text { Row } \\
\text { frequ. } \\
\text { (in \%) }\end{array}$ \\
\cline { 2 - 11 } \\
\hline $\begin{array}{l}\text { Lack of } \\
\text { financial means }\end{array}$ & 321 & $67.4 \%$ & $27.9 \%$ & 424 & $72.5 \%$ & $36.8 \%$ & 407 & $63.9 \%$ & $35.3 \%$ \\
\hline Limited market & 103 & $21.6 \%$ & $25.6 \%$ & 123 & $21.0 \%$ & $30.5 \%$ & 177 & $27.8 \%$ & $43.9 \%$ \\
\hline $\begin{array}{l}\text { Unstable } \\
\text { political and } \\
\text { economic } \\
\text { situation }\end{array}$ & 296 & $62.2 \%$ & $27.3 \%$ & 388 & $66.3 \%$ & $35.8 \%$ & 401 & $63.0 \%$ & $37.0 \%$ \\
\hline $\begin{array}{l}\text { Disloyal } \\
\text { competition }\end{array}$ & 66 & $13.9 \%$ & $24.5 \%$ & 84 & $14.4 \%$ & $31.2 \%$ & 119 & $18.7 \%$ & $44.2 \%$ \\
\hline Too high taxes & 202 & $42.4 \%$ & $26.3 \%$ & 319 & $54.5 \%$ & $41.5 \%$ & 247 & $38.8 \%$ & $32.2 \%$ \\
\hline Other & 7 & $1.5 \%$ & $53.8 \%$ & 4 & $.7 \%$ & $30.8 \%$ & 2 & $.3 \%$ & $15.4 \%$ \\
\hline
\end{tabular}

Source: Author

Table 10. The reasons for the lack of confidence in banks and other institutions which offer financial means for start ups

\begin{tabular}{|l|c|c|c|c|c|c|c|c|c|}
\hline & \multicolumn{7}{|c|}{2010} & \multicolumn{3}{c|}{2011} & \multicolumn{3}{c|}{2012} \\
\cline { 2 - 10 } & Frequ. & $\begin{array}{c}\text { Column } \\
\text { frequ. } \\
\text { (in \%) }\end{array}$ & $\begin{array}{c}\text { Row } \\
\text { frequ. } \\
\text { (in \%) }\end{array}$ & Frequ. & $\begin{array}{c}\text { Column } \\
\text { frequ. } \\
\text { (in \%) }\end{array}$ & $\begin{array}{c}\text { Row } \\
\text { frequ. } \\
\text { (in \%) }\end{array}$ & Frequ. & $\begin{array}{c}\text { Column } \\
\text { frequ. } \\
\text { (in \%) }\end{array}$ & $\begin{array}{c}\text { Row } \\
\text { frequ. } \\
\text { (in \%) }\end{array}$ \\
\hline $\begin{array}{l}\text { High interest } \\
\text { rates }\end{array}$ & 236 & $75.2 \%$ & $26.9 \%$ & 320 & $80.4 \%$ & $36.4 \%$ & 322 & $75.6 \%$ & $36.7 \%$ \\
\hline $\begin{array}{l}\text { Inappropriate } \\
\text { instruments of } \\
\text { securing loans }\end{array}$ & 72 & $22.9 \%$ & $21.6 \%$ & 142 & $35.7 \%$ & $42.5 \%$ & 120 & $28.2 \%$ & $35.9 \%$ \\
\hline $\begin{array}{l}\text { Big } \\
\text { administration }\end{array}$ & 75 & $23.9 \%$ & $21.0 \%$ & 156 & $39.2 \%$ & $43.7 \%$ & 126 & $29.6 \%$ & $35.3 \%$ \\
\hline $\begin{array}{l}\text { Long process for } \\
\text { getting financial } \\
\text { means }\end{array}$ & 91 & $29.0 \%$ & $26.3 \%$ & 116 & $29.1 \%$ & $33.5 \%$ & 139 & $32.6 \%$ & $40.2 \%$ \\
\hline Rest & 17 & $5.4 \%$ & $37.8 \%$ & 21 & $5.3 \%$ & $46.7 \%$ & 7 & $1.6 \%$ & $15.6 \%$ \\
\hline Chi-square test: $\mathrm{X}^{2}=49.207 ; \mathrm{df}=10 ; \mathrm{p}=.000$ \\
\hline
\end{tabular}

Source: Author 
These indices point at inadequate policy of the state towards youth as potential entrepreneurs and the private entrepreneurship itself. Unstable political and economical situation, poor financial support to economy and too high taxes have been repeated for years which points at the lack of state's readiness to solve these problems. These unsolved problems influence the existence of appropriate ambience for business start up. Tax policy represents one of the greatest problems not only for those who want to start up their own business but also for those who have been working in it for years. Associations of entrepreneurs have expressed certain remarks related to the work of tax administration and negative influence of some taxes on normal functioning of companies especially SMEs but, unfortunately, these problems are still present. In addition, there are no specialized institutions which support youth to start up their own business, so there are many reasons for unsatisfaction with entrepreneurial ambience. Without appropriate encouraging ambience it is not possible to direct young people towards entrepreneurial behaviour seriously.

Table 11. Role of the state in stimulating youth to start up business

\begin{tabular}{|c|c|c|c|c|c|c|c|c|c|}
\hline & \multicolumn{9}{|c|}{ Year } \\
\hline & \multicolumn{3}{|c|}{2010} & \multicolumn{3}{|c|}{2011} & \multicolumn{3}{|c|}{2012} \\
\hline & Frequ. & $\begin{array}{l}\text { Column } \\
\text { frequ. } \\
\text { (in \%) }\end{array}$ & \begin{tabular}{|} 
Row \\
frequ. \\
(in \%)
\end{tabular} & Frequ. & \begin{tabular}{|c|} 
Column \\
frequ. \\
(in \%)
\end{tabular} & $\begin{array}{l}\text { Row } \\
\text { frequ. } \\
\text { (in \%) }\end{array}$ & Frequ. & \begin{tabular}{|c|} 
Column \\
frequ. \\
(in \%)
\end{tabular} & $\begin{array}{l}\text { Row } \\
\text { frequ. } \\
\text { (in \%) }\end{array}$ \\
\hline Favourable loans & 343 & $64.8 \%$ & $31.0 \%$ & 399 & $66.5 \%$ & $36.1 \%$ & 364 & $56.5 \%$ & $32.9 \%$ \\
\hline Education & 231 & $43.7 \%$ & $28.1 \%$ & 277 & $46.2 \%$ & $33.7 \%$ & 313 & $48.6 \%$ & $38.1 \%$ \\
\hline \begin{tabular}{|l|} 
laws/regulations \\
related to youth as \\
entrepreneurs
\end{tabular} & 187 & $35.3 \%$ & $29.3 \%$ & 233 & $38.8 \%$ & $36.5 \%$ & 219 & $34.0 \%$ & $34.3 \%$ \\
\hline $\begin{array}{l}\text { Development of } \\
\text { new business } \\
\text { centres and } \\
\text { incubators } \\
\end{array}$ & 125 & $23.6 \%$ & $30.1 \%$ & 137 & $22.8 \%$ & $33.0 \%$ & 153 & $23.8 \%$ & $36.9 \%$ \\
\hline $\begin{array}{l}\text { Regulation of } \\
\text { market }\end{array}$ & 146 & $27.6 \%$ & $27.8 \%$ & 185 & $30.8 \%$ & $35.2 \%$ & 195 & $30.3 \%$ & $37.1 \%$ \\
\hline $\begin{array}{l}\text { Promotion of the } \\
\text { concept of youth } \\
\text { as entrepreneurs }\end{array}$ & 158 & $29.9 \%$ & $28.7 \%$ & 204 & $34.0 \%$ & $37.0 \%$ & 189 & $29.3 \%$ & $34.3 \%$ \\
\hline Other & 5 & $.9 \%$ & $31.3 \%$ & 7 & $1.2 \%$ & $43.8 \%$ & 4 & $.6 \%$ & $25.0 \%$ \\
\hline
\end{tabular}

Source: Author

The greatest number of interviewed, even $88.5 \%\left(X^{2}(1, N=1988)=\right.$ 1180.596, $p=.000)$, think that the state must have key role in stimulating Industrija, Vol.41, No.3, 2013 
youth for business start up. Respondents emphasize the following stimulatng measures which should be taken by the state (table 11): favourable loans, education and laws/regulations related to youth as entrepreneurs. Considering the activities which are carried out in Serbia these answers are different from the trend in 2008 and 2009 when Promotion of the concept of youth as entrepreneurs represented, in students' opinion, key way of state support.

\subsection{Discussion}

For successful economic recovery of Serbian economy the priority is stable political and economic situation which would contribute to more secure business performance and also positive signal for birth of new companies. Unfortunately, there are lots of monopolistic and privileged companies on the market which additionally discourages other companies to improve competition on domestic market. Lack of financial means is an old problem not only for Serbian companies but also for companies in developed countries and EU as well. However, the solution may be found in more favourable offer of current loans and in encouragement of youth to team with others and in that way provide bigger financial means.

For successful managing of companies knowledge is necessary, whether achieved in formal or informal education. In the Figure 3 three fields which youth lack for managing their own business are presented: elements of entrepreneurship and small business, elements of finance and accounting and foreign languages. The first two fields point at the fact that at faculties and in school system in general students should be more concretely presented knowledge from this field. It means that they should achieve skills through practical work. The same is also valid for use of foreign languages which, beside information literacy, represent the basic condition for work in modern business.

It can be concluded from everything said before that young people still do not have enough self-confidence for business start up. There are lots of reasons for that and one of them is education of youth from the field of entrepreneurship. Current situation is unsatisfactory and new ways for education and promotion of entrepreneurship should be found. Young people in Serbia have a wish but they are not trained enough for developing entreneurial initiative and business start up. Another reason for their lack of self-confidence is inappropriate ambience for encouraging entrepreneurship of youth. 
Ćoćkalo D. et al.: Quality of Business, Entrepreneurship Education and Business...

\section{Conclusion}

Unemployment is a consequence of global economic crisis and it represents one of the most serious economic problems for every government. Young people are one of the most endangered age categories hit by economic crisis. European Commission, in the program Europe 2020, as one of economic priorities represents reducing unemployment of youth and also their encouragement for entrepreneurship and business start up. In relation to this it has started certain programs for support of youth with the aim of achieving entrepreneurial knowledge and its practical use.

Beside insufficient competitiveness of its economy, poor productivity and low technological level Republic of Serbia has high unemployment rate which represents one of the biggest economic problems. Young people in Serbia have problems to find job and according to National Employment Service statistics this trend is increasing especially related to youth. The issue of entrepreneurship is mentioned but more through individual activities of some NGO than through state institutions. Inspite of longlasting talking about youth and their problems relating to their involvement in business there is still inappropriate ambience for their realization.

The research "Analysis of attitudes of the young in relation to own business start up by implementation of corporative responsible business and improving company's competitiveness" which was realized from 2008-2012 on the territory of Republic of Serbia proved several facts that have to be taken into account if we want to encourage the young towards entrepreneurship:

- young people want to start up their own business;

- lack of financial means and unstable political and economic situation represent the reasons for preventing young people from business start up;

- lack of financial means, unstable political and economic situation as well as bad tax policy distract young people from business start up;

- young people think that education is necessary for improving their entrepreneurial knowledge;

- absence of appropriate ambience for business start up and

- key role of state in creating business ambience.

The following state institutions have significant role in creating business ambience: Ministry of Education, Science and Technological Development, Ministry of Finance and Economy, Ministry of Sports and Youth, National Agency for Regional Development, SIEPA. Professional associations also have an important role: Association of entrepreneurs, Serbian Chamber of Commerce, Belgrade Chamber of Commerce, Association of Small and 
Middle enterprises and entrepreneurs of Republic of Serbia, state and private universities, NGO, international organizations. They all have to contribute to making more efficient system for encouraging young people for business start up and for improving their entrepreneurial knowledge that will improve quality of business performance.

\section{References}

Aldrich, H. E., Renzulli, L. A., \& Langton, N. (1998). Passing on privilege : resources provided by self-employed parents to their self-employed children. Research in social stratification and mobility: the official journal of the ISA RC28 on Social Stratification and Mobility, 16, 291-317.

Berglund, H., \& Wennberg, K. (2006). Creativity among entrepreneurship students: comparing engineering and business education. Int. J. Cont. Engineering Education and Lifelong Learning, 16(5), 365-379.

Bhandari, N. C. (2006). Intention for Entrepreneurship among Students in India. Journal of Entrepreneurship, 15(2), 169-179. doi: 10.1177/097135570601500204

Boissin, J.-P., Branchet, B., Emin, S., \& Herbert, J. I. (2009). Students and entrepreneurship: a comparative study of France and the United States. Journal of Small Business and Entrepreneurship, 22(2), 101-122.

Crant, M. J. (1996). The proactive personality scale as a predictor of entrepreneurial intentions. Journal of Small Business Management, 34(3), 42-49.

Đorđević, D., Bogetić, S., \& Ćoćkalo, D. (2010a). Razvoj preduzetničkog ponašanja kod mladih u Republici Srbiji. Megatrend revija (Megatrend Review), 7(21), 6378.

Đorđević, D., Ćoćkalo, D., \& Bogetić, S. (2010b). Preduzetničko ponašanje kod mladih - rezultati istrživanja u Srbiji (The Youth's Enterprising Behaviour -The Research Results From Serbia). Ekonomske teme (Economic Themes), 3/2010, 467-479.

EUCommission. (2012). Flash Eurobarometer No 354, Entrepreneurship in the EU and beyond, June - August 2012 Retrieved 3.4.2013, from http://ec.europa.eu/public opinion/flash/fl 283 en.pdf

EUCommission. (2013a, 9.1.2013). Entrepreneurship 2020 action plan. Reigniting the entrepreneurial spirit in Europe Retrieved 3.4.2013, from http://www.unescochair.uns.ac.rs/sr/docs/enterpreneurship2020ActionPlan.pdf

EUCommission. (2013b). Citizens' summary: Entrepreneurship 2020 - EU action plan Retrieved 3.4.2013, from http://ec.europa.eu/internal market/copyright/docs/ipr strategy/citizenssummary en.pdf

EUCommission. (2013c, 12.3.2013). Youth Employment Initiative Retrieved 3.4.2013, from http://eurlex.europa.eu/LexUriServ/LexUriServ.do?uri=COM:2013:0144:FIN:EN:PDF

EUCommission. (2013d, 15.3.2013). Youth Employment Action Teams: Update for the Spring European Council Retrieved 3.4.2013, from http://ec.europa.eu/europe2020/pdf/barroso/report en.pdf 
Franke, N., \& Lüthje, C. (2004). Entrepreneurial Intentions of Business Students: A Benchmarking Study. International Journal of Innovation and Technology Management, 1(3), 269-288.

Gartner, W. B. (1988). Who is an entrepreneur? Is the Wrong Question. American Journal of Small Business, 12, 11-22.

Gasse, Y., \& Tremblay, M. (2011). Entrepreneurial Beliefs and Intentions: A CrossCultural Study of University Students in Seven Countries. International Journal of Business, 16(4), 303-314.

Harris, M. L., \& Gibson, S. G. (2008). Examining the entrepreneurial attitudes of US business students. Education + Training, 50(7), 568 - 581.

Johannisson, B., Landström, H., \& Rosenberg, J. (1998). University training for entrepreneurship - an action frame of reference. European Journal of Engineering Education, 23(4), 477-496.

Kolvereid, L. (1996). Organizational employment versus self-employment: Reasons for career choice intentions. Entrepreneurship: Theory and Practice, 20(3), 23-31.

OECD. (2009). Evaluation of Programmes Concerning Education for Entrepreneurship Retrieved 3.4.2013, from http://www.oecd.org/industry/smes/42890085.pdf

RSNSZ. (February 2013). Monthly Statistic Bulletin, Unemployment and Employment in the Republic of Serbia Retrieved 27.9.2013, from http://www.nsz.gov.rs/live/dokumenti/statisti ki bilteni nsz.cid667

RZSRS. (2013). Labour Force Survey Retrieved 27.9.2013, from http://webrzs.stat.gov.rs/WebSite/Public/PageView.aspx?pKey=27

Scheinberg, S., \& MacMillan, I. (1988). An eleven country study of the motivations to start a business. Paper presented at the Frontiers of entrepreneurship research.

Scherer, R. F., \& Brodzinski, J. D. (1990). Entrepreneur career selection and gender: A socialization approach. Journal of Small Business Management, 28(1), 37-44.

Schwarz, E. J., Wdowiak, M. A., Almer-Jarz, D. A., \& Breitenecker, R. J. (2009). The effects of attitudes and perceived environment conditions on students' entrepreneurial intent: An Austrian perspective. Education + Training, 51(4), 272 - 291.

Segal, G., Borgia, D., \& Schoenfeld, J. (2005). The motivation to become an entrepreneur. International Journal of Entrepreneurial Behaviour \& Research, 11(1), 42 - 57.

van der Zwan, P., Zuurhout, P., \& Hessels, J. (January 2013). Entrepreneurship education and self-employment: The role of perceived barriers Retrieved 3.4.2013, from http://www.ondernemerschap.nl/pdf-ez/H201301.pdf

Vukmirović, N. (2005). Inovacije i preduzetnički intelidžens u funkciji razvoja korporativnog preduzetništva. Industrija, 33(2-3), 27-43. 